\title{
Research on Traditional Culture to Promote Ideological and Political Education of College Students
}

\author{
Ru Lan \\ Guangzhou Sports Polytechnic, Guangzhou Guangdong, 510650, China
}

Keywords: Traditional culture, Ideological and political education, Value, Teaching implementation

\begin{abstract}
China has five thousand years of civilization heritage, traditional culture is a rich and diverse country. Therefore, in today's society, we will continue to carry forward the traditional culture is important to pass down the responsibility of every Chinese person's shoulder. This paper aims to promote the use of traditional culture in today's ideological and political education of college students, to explore the deep traditional cultural values and educational value of ideological and political education in the implementation strategy.
\end{abstract}

\section{Introduction}

Traditional Chinese history and culture, it is mainly to include the intellectual, moral, artistic, custom and system-based human material and spiritual creative achievements. These results in today's society have been gradually transformed into China ingrained ideas of social production and life to play a very important and special role. How to make good use of the traditional culture in the ideological and political education to help them achieve understanding of traditional culture, but also be able to get life sublimation ideological level, we must first understand the traditional culture of its own connotation and meaning of value that exists.

\section{Connotations and Characteristics of Chinese Traditional Culture}

\section{Connotations.}

A contemporary perspective on the perspective of traditional Chinese culture, people on the "culture" have to understand the word of the narrow and broad points. Generalized culture refers to the practice of human activities in the social and historical development process pay, spiritual wealth and material wealth they create is the sum of traditional culture; and the culture is especially narrow spiritual and cultural level, it symbolizes not only It is the spiritual and cultural products, but also includes social ideology. Traditional culture is built on a narrow basis upon material culture.

Chinese people as the nation's heritage, it is necessary to continue and carry forward the cultural heritage. And college students about to enter the force as a community, into the traditional culture of their ideological and political education, not only to make itself more rich educational content, interesting and humane, but also to correct for the Student view of society and values, for the national social the positive and healthy development of great help.

\section{Characteristics.}

Chinese traditional culture has its own independent of natural conditions and historical environment; these factors balance each other each other's role. In conclusion, China's traditional culture is based on the "home country isomorphic" features small-scale peasant family system and autocracy. It is this relatively strict social structure and relatively closed national environmental conditions that created the ancient oriental unique distinctive traditional culture. In particular, the specific features of Chinese traditional culture have the following three points.

\section{1) Independence}

The reason why Chinese traditional culture is independent because it is a vast land, different regions have different regional cultures. In such a desert north west Highlands, the southeast coastal countries, coupled with underdevelopment of ancient transportation, culture sprout from the respective regions are also formed spontaneously, they self-contained, almost no fusion point, so China will have 56 ethnic groups, 56 kinds of national culture. But Chinese traditional culture is in 
such a form of culture highly fragmented state, it can still maintain the integrity of the entire country unified domain, which is the world any nation are hard to do.

\section{2) Containment}

Chinese traditional culture has created its diversity inclusiveness, thereby forming a unity. In fact, this is mainly because Chinese traditional culture is rooted, it is this foundation to let the Chinese people to the cultural construction has a very broad and inclusive attitude, always uphold the "be tolerant to diversity, tolerance is a virtue," the ideological basis of the principle of . Can such as the four great inventions, the quintessence of drama, ceramics, see the Silk Road from China enduring Chinese traditional culture with a variety of multi-ethnic culture, and even in the world are also popular reasons. So that Chinese traditional culture is extremely strong inclusive, it is this inclusiveness has evolved for compatibility with a variety of regional culture, the Chinese people in the long historical process has always maintained a tolerant attitude to accommodate heterogeneous culture, and to transform, into their own use.

\section{3) Boundedness}

That everything with the limitations of traditional Chinese culture is no exception. In its evolution is inevitable that the family system, hierarchy, status quo, theocratic, monarchical, patriarchal culture such core system, which for the development of modern society is not feasible, since they are not humane, even hurt to the people themselves. In today's China, to carry forward the traditional culture and heritage should not become an obstacle to people's lives, creativity and entrepreneurial shackles, but should be a perfect posture in front of people, to promote the development of human society, the great heritage of the Chinese nation guidepost [1].

\section{The value role of Chinese Traditional Culture plays in Ideological and Political Education}

Integration of Chinese traditional culture in the ideological and political education of college students and mental ability to grow is helpful. In this paper, the traditional culture in the ideological and political education to briefly touch points value the role it played.

Value role for students to establish a correct "Three Views".

The so-called ideological and political education of "Three Views" refers to the worldview, values and philosophy at the University of the Establishment of "Three Views" ideological and critical period, Chinese traditional culture is bound to intervene to guide students to rediscover the value of Chinese traditional ethics, traditional culture and depth to improve their own personality, ideal shape. The so-called Confucian often talked about "for oneself" and "to have", these are the requirements of traditional culture in the personality of their own to achieve a certain ideal state. Therefore, Confucius would argue that people in the state to meet the basic material life, the more should pursue lofty spiritual world, the moral ideal of life as the highest level needs to locate. For college students, it is no better ideological and political education template, so the value of the role of traditional culture lies in the depth of Developing Students' Three Outlooks ".

Value role for students establish positive attitude towards life.

The so-called "the gentleman to self-reliance", for college students, ideological and political education is to establish their correct outlook on life, values and world view. Want to achieve on the basis of these realities is the depth of integration of traditional Chinese culture in which political education system, dissemination of traditional Chinese culture, people self-improvement, tenacious struggle consciousness, such as Kuafu' s pursuit of the sun, the Foolish Old Man who moves the mountains, Jingwei fills up the sea. Of course, traditional culture and education will also integrate a negative example, such as "Water Margin" and so on. Therefore we can say, 5,000 years of Chinese history of traditional culture is very rich, these bring to college students' school life, not only worked hard to motivate them, but also make them have a more noble character awareness and more positive attitude to life.

\section{Help students to build positive patriotism.}

Students learn traditional culture today is necessary, because it is a building of great patriotism, hope the Chinese people of all nationalities can seek common ground and jointly safeguard the 
Chinese homeland, and thrive in this land, help each other, more co-founder of human civilization. In the ideological and political education can integrate people with lofty ideals of many nationalities in the history of the story, outstanding contribution they have made to the motherland, to stimulate the spirit of love for the motherland more students, to remain. On the external front, the traditional culture based on ideological and political education of college students can also promote the establishment of harmony, united in opposing separatism patriotism [2].

\section{Value realization strategy of traditional culture to promote ideological and political education college students}

Traditional culture in the ideological and political education should expand from multiple perspectives and in-depth analysis, we hope from the fusion of three aspects of traditional culture and teaching colleges and universities, campus culture and the construction of social and cultural activities to explore the value of ideological and political education of college students implement countermeasures.

\section{Integration of traditional culture and college education activities.}

\section{1) Integration of curriculum provision}

According to the national "25" raised "about" "Cultural Development Plan during the" Eleventh Five in Article XIII "domestic colleges and universities should actively create conditions for all college students to open Chinese traditional culture, Chinese culture-based courses strengthen the teaching of traditional culture in university infrastructure disciplines and related disciplines to promote common development. "at present, many colleges and universities actually very lack of traditional culture and popularization of compulsory course setting, most of the ideological and political education as an elective course exist, and not subject to a correct understanding of the school and its students, which to a large extent hindered the extension of the traditional culture and education in the university smoothly. So it should be in the curriculum, especially in the full effort in setting the ideological and political education courses up and down, and the sound of traditional culture into the curriculum them.

First, the course structure, should be implemented in colleges and universities in the low proportion of humanities and social sciences to join in and give it to build a new curriculum system, strengthening the effective provision of the relevant courses. Such as Introduction to Chinese culture, the ancient Chinese teaching, etc., combined with each other by the reality of College Students needs to improve the cultural connotation of the ideological and political education courses, and can be appropriately increased class capacity.

Secondly, in the course content and teaching materials compiled, should develop a lot of creative teaching and cultural knowledge, more traditional culture advocated spiritual, moral teaching rites into the system. For example select some Confucian classics in the classic text Pre-Qin and into ideological and political teaching them, combine them reality, social life, for students to create an idea of intimacy education, students may resolve before learning the existence of confusion.

2) Integration of multimedia technology

Today is the multimedia information technology society, so this technology has gradually spread to all areas of social development. To spread traditional culture by means of multimedia technology in the ideological and political education is quite effective method, it can make classroom teaching really "live" together, more convenient and easy. It solves the status of traditional Students are passive inculcation of knowledge, but to encourage students through computer technology to Internet-based multimedia culture Thought of interactive environments. As former President $\mathrm{Hu}$ Jintao said, "In the new century, the health of college students in an ideological and political education should actively use modern means of information technology, which facilitates the spread of the fine traditional culture, but also allows the initiative to grasp the ideological and political education in colleges and universities. "Therefore, the use of multimedia technology to spread traditional culture and cultural content, so as to explore the ideological and political education teaching approach is quite worthy of praise. 


\section{Integration of traditional culture and construction of campus culture.}

In 2012, China's State Council "on the strengthening of teachers of opinions", which content represents teachers should enhance their own ideological and political quality, and to uphold and improve the ideological and political theory and cultural learning system innovation in the basis of these principles the ideological and political education with Chinese characteristics theoretical system of socialism spread out. Teachers as "preaching Tuition FAQ" who must improve students' humane quality, the development of Chinese traditional culture and thought and effort, thereby allowing the fine traditional Chinese culture is more powerful, so that more Chinese people will have a centripetal force. For colleges and universities, to take a good spread of the baton of traditional culture, based on college students' moral character to improve the quality of traditional cultural content to dig, cultivate the moral cultivation, and also guide them to love Chinese culture is more patriotic. Accordingly, aspects of Universities should do two things.

First, through the mass media to promote the traditional culture of ideological and political education in the direction of development, such as radio, newspapers, magazines, television, and so the media and the media can play this role.

Second, the campus radio is the use of key multimedia communication platform of the ideological and political education. The platform according to contemporary college students circle the popular hobbies, state of mind to implement and disseminate the ideological and political content of traditional culture, and from time to time to open the line for students exchanges, experience experience will be like. In addition, the forum organized students to watch Sinology class program can enrich their traditional culture and knowledge, combined with ideological and political education and then look at the summary of traditional culture to further strengthen the college students' world view, values and outlook on life.

\section{Integration of traditional culture and social activities.}

In addition to classroom teaching, extracurricular activities based on traditional culture but also follow-up, from various angles to strengthen the promotion of ideological and political education of college students.

In an example of traditional festivals, traditional Chinese festivals and has a rich source of profound cultural connotations. But with the reform and opening up, continue to impact on Western culture, Chinese traditional festivals in the country's situation more awkward, and even forgotten. So for this phenomenon than on ideological and political education to university students should be pulled to the classroom, leading them to participate more folk customs and festivals which make their personal spiritual nurture cultural resources at the root, and let them pass enjoy the traditional festival of the Chinese nation's most traditional superior side, personal college students strengthen understanding of traditional festivals, it is conducive to their correct ideological and political ideals, to make them more love for the motherland. As Nanjing University Folk Art Research Director Professor Chen Jingran said, "Our many years of education in colleges and universities committed to the protection of traditional culture and utilization of mining such as the Dragon Boat Festival, Mid-Autumn Festival, the Spring Festival this major traditional festival culture connotation of their research but also to national cohesion, strengthen a country's soft power. it promotes the prosperity of our culture, and development scene, it is worth focusing on protection. [3] "

\section{Conclusions}

The traditional culture into the current ideological and political education of college students, with its realistic and forward-looking. By fusion of the two, ideological and political education will become more rich and interesting and open, so that contemporary college students a taste of the different ideological and political education content and meaning. Therefore, in the future, that a comprehensive education should continue to carry forward the traditional culture, correct values of the future generation of college students continue to enrich and innovation. 


\section{Acknowledgments}

This paper belongs to 2015 college basic level party building “secretary project”.

\section{References}

[1] Li Zongyun. Value of Traditional Culture and its implementation in the ideological and political education, Northeast Normal University,2008.2-6.

[2] Zhang Wei. On the Value of Chinese Traditional Culture in Contemporary Ideological and Political Education of College Students, Shandong University, 2010.44-48.

[3] Li Dewan. The value of the fine traditional culture and the Way in Ideological and Political Education, Liaoning Normal University,2013.17-20. 